\title{
Protective Effect of Intrarenal Calcium Membrane Blockers Before or After Renal Ischemia

\author{
Functional, Morphological, and \\ Mitochondrial Studies
}

Thomas J. Burke, Patricia E. Arnold, Joel A. Gordon, Ruth E. Bulger, Dennis C. Dobyan, and Robert W. Schrier Department of Medicine, University of Colorado Health Sciences Center, Denver, Colorado 80262, and Department of Pathology and Laboratory Medicine, University of Texas Health Sciences Center at Houston, Texas 77004

bstract. The present study examined whether a pre- or postischemic infusion of verapamil $(\mathrm{V})$ or a postischemic infusion of nifedipine $(\mathrm{N})$, drugs which block calcium $\left(\mathrm{Ca}^{++}\right)$influx across plasma membranes, provides protection against ischemic acute renal failure (ARF) in dogs. Renal hemodynamics and excretory function were examined $1 \mathrm{~h}$ (initiation phase) and $24 \mathrm{~h}$ (maintenance phase) after a 40-min intrarenal infusion of norepinephrine (NE). In each case, the uninfused contralateral kidney served as control. Four groups were studied: ( $a$ ) dogs receiving NE alone; $(b)$ dogs receiving an intrarenal infusion of $\mathrm{V}$ for $30 \mathrm{~min}$ before $\mathrm{NE}$ ( $\mathrm{V}$ $+\mathrm{NE}$ ); (c) dogs in which intrarenal $\mathrm{V}$ was infused for 2 $h$, beginning immediately after completion of NE infusion $(\mathrm{NE}+\mathrm{V})$; and $(d)$ dogs in which intrarenal $\mathbf{N}$ was infused for $2 \mathrm{~h}$, beginning immediately after completion of $\mathrm{NE}$ infusion $(\mathrm{NE}+\mathrm{N})$. Glomerular filtration rate (GFR) in the NE kidneys, as assessed by inulin clearance, at 1 and $24 \mathrm{~h}$ averaged $2.4 \pm 1.1$ and $5.0 \pm 2.0 \mathrm{ml} / \mathrm{min}$, respectively, as compared with control kidney GFRs of $28.0 \pm 3.5$ and $43.8 \pm 5.0 \mathrm{ml} / \mathrm{min}$, respectively (both at least $P<0.01$ ). In the $\mathrm{V}+\mathrm{NE}$ group, GFR at 1 and $24 \mathrm{~h}$ averaged $15.0 \pm 5.5$ and $31.0 \pm 4.5 \mathrm{ml} / \mathrm{min}$, respectively, both at least $P<0.05$ as compared with values from NE kidneys. GFRs in the $\mathrm{NE}+\mathrm{V}$ group averaged $15.0 \pm 2.4$ and $16.3 \pm 3.6 \mathrm{ml} / \mathrm{min}$ at 1 and $24 \mathrm{~h}$, both at least $P<0.02$ as compared with values from NE kidneys. GFR in the $\mathrm{NE}+\mathrm{N}$ group averaged $18.6 \pm 6.0 \mathrm{ml} / \mathrm{min}$

Received for publication 16 August 1983 and in revised form 2 July 1984.

J. Clin. Invest.

(c) The American Society for Clinical Investigation, Inc. 0021-9738/84/11/1830/12 \$1.00

Volume 74, November 1984, 1830-1841 at $24 \mathrm{~h}(P<0.05$ as compared with GFRs in the NE kidneys). In addition, function of cortical mitochondria (Mito) was examined at the end of the 40-min NE infusion and after 1 and $24 \mathrm{~h}$ of reperfusion in the $\mathrm{NE}$ alone and $\mathrm{NE}+\mathrm{V}$ groups. Mito respiration, assessed by acceptor control ratios, was reduced at each period in the NE alone kidneys. After $24 \mathrm{~h}$, these Mito had accumulated $\mathrm{Ca}^{++}$and exhibited reduced $\mathrm{Ca}^{++}$uptake and increased $\mathrm{Ca}^{++}$release rates. Mito from $\mathrm{NE}+\mathrm{V}$ kidneys respired normally, did not accumulate $\mathrm{Ca}^{++}$, and exhibited no alterations in $\mathrm{Ca}^{++}$uptake or release. Light and electron microscopy also demonstrated morphological protection of $\mathrm{V}$ against tubular necrosis and cell injury. Mito from the $\mathrm{NE}+\mathrm{N}$ kidneys also respired normally and did not accumulate significant amounts of $\mathrm{Ca}^{++}$. The results of the present studies therefore demonstrate that chemically dissimilar calcium entry blockers exert substantial functional, cellular, and morphological protection against experimental ischemic ARF. These findings are compatible with the hypothesis that increased cytosolic $\mathrm{Ca}^{++}$is critically important in the maintenance of renal vasoconstriction and the development of cellular necrosis with subsequent tubular obstruction in NE-induced ischemic ARF. $\mathrm{V}$ or $\mathrm{N}$ may provide protection against renal injury by retarding any increase in cytosolic $\mathrm{Ca}^{++}$in renal vasculature and epithelium.

\section{Introduction}

Norepinephrine $(\mathrm{NE})^{1}$-induced acute renal failure (ARF) in the dog is characterized by low glomerular filtration rate (GFR)

1. Abbreviations used in this paper: $\mathrm{ACR}$, acceptor control ratio; $\mathrm{ARF}$, acute renal failure; $\mathrm{CEB}, \mathrm{Ca}^{++}$entry blocker; $\mathrm{FE}_{\mathrm{Na}}$, fractional sodium excretion; GFR, glomerular filtration rate; Mito, mitochondria, mito- 
a secondary effect of renal vasoconstriction with reduced glomerular capillary pressure and by tubular obstruction (1). Certain drugs that cause renal vasodilation and increase solute excretion such as prostaglandin $\mathrm{E}_{2}$, mannitol, and furosemide have been shown to reduce the severity of renal dysfunction in this model of ARF (1-5). Other vasodilators, however, such as secretin and acetylcholine, which increase renal blood flow (RBF) with or without enhanced solute excretion, are not protective in this model of ischemic ARF (4-6).

Since intracellular calcium $\left(\mathrm{Ca}^{++}\right)$in vascular smooth muscle and renal tubular epithelial cells could be involved in renal vasoconstriction (7) and epithelial cell necrosis (8), respectively, it seemed important to examine whether a blocker of cellular $\mathrm{Ca}^{++}$influx would protect against the functional and cellular consequences of renal ischemia. This was a particularly intriguing prospect, since studies from our laboratory had shown that intrarenal verapamil (V) causes profound renal vasodilation and increases solute excretion (9). The present study was therefore undertaken to examine the intrarenal effect of the $\mathrm{Ca}^{++}$entry blocker (CEB), $\mathrm{V}$, on the functional, morphological, and mitochondrial (Mito) consequences of acute renal ischemia. Early (initiation) and late (maintenance) studies were performed as was intervention with $\mathrm{V}$ before and after the ischemic renal insult. Nifedipine $(\mathrm{N})$ was also infused after norepinephrine (NE) to test whether a dissimilar CEB would exert effects similar to those observed with $\mathrm{V}$ treatment.

\section{Methods}

Mongrel dogs of both sexes were used in this study. Anesthesia was induced with intravenous sodium pentobarbital $(25 \mathrm{mg} / \mathrm{kg})$. The method of creating unilateral NE-induced ARF has been described in detail previously $(1,3,4)$. Contralateral uninfused kidneys served as controls.

\section{$N E$ infused alone (NE) group}

Initiation phase of $A R F$. For these experiments $(n=9)$, studies were performed before and for $1 \mathrm{~h}$ after NE-induced ARF. Both ureters were isolated through a midline abdominal incision and then cannulated. The left renal artery was isolated, instrumented with a flow probe, and curved 25-gauge needle was placed in the artery near its junction with the aorta. Systemic blood pressure was measured with a transducer (model 377; Harvard Apparatus Co., Inc., The Ealing Corp., South Natick, MA) attached to a femoral artery catheter. Infusions were administered through a femoral vein catheter. Inulin was infused intravenously to establish a plasma concentration of $\sim 20 \mathrm{mg} / \mathrm{dl}$. After an equilibration period of $1 \mathrm{~h}$ and two 15-min control clearance collections, NE $(0.75 \mu \mathrm{g} / \mathrm{kg}$ per min) was infused through the renal artery catheter for $\mathbf{4 0}$ min. Flowmeter readings indicated that RBF fell to zero within $10 \mathrm{~s}$ after the NE infusion was begun. Renal function was reassessed $1 \mathrm{~h}$ later. Inulin clearance was used as an estimate of GFR.

chondrial; N, nifedipine; NE, norepinephrine; $\mathrm{NE}+\mathrm{N}, \mathrm{N}$ infused after $\mathrm{NE} ; \mathrm{NE}+\mathrm{V}, \mathrm{V}$ infused after NE; RBF, renal blood flow; S3, state 3 respiration; $S 4$, state 4 respiration; $V$, verapamil; $V+N E, N E$ infused after V.
Maintenance phase of $A R F$. For these experiments $(n=6)$, studies were performed only $24 \mathrm{~h}$ after the NE infusion. To create ARF, sterile isolation of the left femoral artery was undertaken after anesthesia as described above; a radioopaque catheter was then threaded from the femoral artery into the aorta and guided under fluoroscopic control into the left renal artery. NE was infused for $\mathbf{4 0 ~} \mathrm{min}$; then the catheter was withdrawn, the artery was ligated, and the incision was closed with 4-0 chromic gut. $24 \mathrm{~h}$ later, animals were reanesthetized and prepared for acute clearance studies as described above. Two 20-min urine collections were obtained to measure plasma clearances.

\section{$V$ infused before $N E(V+N E)$ group}

In these experiments, the pre-drug clearance collections were obtained as described above; then $\mathrm{V}$ (dissolved in water, $5 \mu \mathrm{g} / \mathrm{kg}$ per min; Knoll Pharmaceuticals Co., Whippany, NJ) was infused at $0.5 \mathrm{ml} / \mathrm{min}$ into the left renal artery for $30 \mathrm{~min}(n=6)$. During the final $10 \mathrm{~min}$ of this unilateral infusion, two 5-min urine collections were obtained. $V$ infusion was then stopped and the 40-min infusion of $\mathrm{NE}$ was immediately initiated. RBF decreased to zero within $10 \mathrm{~s}$. The remainder of these acute studies were similar to those described above for the initiation phase of ARF. In studies of the maintenance phase of ARF, $\mathrm{V}$ was also infused for $30 \mathrm{~min}$ before $\mathrm{NE}$, and these animals were then studied $24 \mathrm{~h}$ later $(n=6)$.

\section{$V$ infused after $N E(N E+V)$ group}

In these experiments, intrarenal $\mathrm{V}$ infusion (also $5 \mu \mathrm{g} / \mathrm{kg}$ per min at $0.5 \mathrm{ml} / \mathrm{min}$ ) was begun immediately after the $40-\mathrm{min} \mathrm{NE}$ infusion ( $n$ $=7$ ) was completed. Kidneys were removed for Mito studies $1 \mathrm{~h}$ after $\mathrm{V}$ infusion was started; in other experiments $\mathrm{V}$ was infused for $2 \mathrm{~h}$ after NE. In the latter, evaluations of renal functions were made $24 \mathrm{~h}$ after ischemia $(n=6)$

\section{$N$ infused after $N E(N E+N)$ group}

$\mathrm{N}$ was dissolved in absolute ethanol $(15 \mathrm{ml})$ and polyethylene glycol (15 ml, 300-400 mol wt) and brought up to a final volume of $120 \mathrm{ml}$ with distilled water. In these experiments, intrarenal $\mathrm{N}$ infusion $(2.0$ $\mu \mathrm{g} / \mathrm{kg}$ per $\mathrm{min}$ at $1.0 \mathrm{ml} / \mathrm{min}$ ) was begun immediately after completion of the 40-min NE infusion and continued for $2 \mathrm{~h}(n=4)$. Functional studies were performed $24 \mathrm{~h}$ later and the kidneys were removed for Mito studies. $\mathrm{N}$ in the reservoir and perfusion line was protected from exposure to light throughout the preparatory and infusion period.

\section{Mito respiration studies}

In these experiments, at the end of the NE infusion (before reflow) or at either $1 \mathrm{~h}$ (initiation phase) or $24 \mathrm{~h}$ (maintenance phase), each renal artery was clamped and the control and infused kidneys were removed. Mito studies were not performed in the $V+N E$ group since these data have been previously reported from our laboratory (10). Cortex was separated from medulla and immediately immersed in chilled media containing $210 \mathrm{mM}$ mannitol, $70 \mathrm{mM}$ sucrose, $0.1 \mathrm{mM}$ EGTA, ${ }^{2}$ $0.5 \%$ bovine serum albumin (BSA) and buffered to $\mathrm{pH} 7.4$ with $2 \mathrm{mM}$

2. This concentration of EGTA $(0.1 \mathrm{mM})$ may not totally prevent in vitro $\mathrm{Ca}^{++}$uptake by Mito during the separation phase performed at $4^{\circ} \mathrm{C}$, but $1.0 \mathrm{mM}$ EGTA may actually decrease Mito $\mathrm{Ca}^{++}$in vitro. Recent studies have shown results that are qualitatively similar to the present results when the Mito isolation in vitro was performed in the presence of ruthenium red which totally blocked in vitro $\mathrm{Mito}^{\mathrm{Ca}}{ }^{++}$ - uptake $(11,12)$. This approach, however, does not allow for assessment of the uptake and release of $\mathrm{Ca}^{++}$by Mito. 
K-Hepes. The tissue was scissor minced and homogenized (20\% wt/ vol) on ice for $\sim 5-10 \mathrm{~s}$ by use of a homogenizer (Polytron; Brinkmann Instruments Inc., Westbury, NY). The homogenate was centrifuged at $4^{\circ} \mathrm{C}$ at $750 \mathrm{~g}$ twice to remove cellular debris. The resultant supernate was then centrifuged at $8,000 \mathrm{~g}$ to obtain the Mito fraction. The Mito pellet was washed twice with media from which the BSA and EGTA were omitted, and resuspended at a concentration of $\sim 100 \mathrm{mg}$ protein/ $\mathrm{ml}$. Mito protein content was determined by the method of Murphy and Kies (13) using a spectrophotometer (model 25; Beckman Instruments Inc., Fullerton, CA).

Mito $\mathrm{O}_{2}$ consumption was measured polarographically in a closed reaction vessel fitted with a Clark $\mathrm{O}_{2}$ electrode (Yellow Springs Instrument Co., Yellow Springs, $\mathrm{OH}$ ) at $25^{\circ} \mathrm{C}$ in a volume of $1.7 \mathrm{ml}$. The incubation medium was composed of $120 \mathrm{mM} \mathrm{KCl}, 2 \mathrm{mM}$ potassium-phosphate, $4 \mu \mathrm{M}$ rotenone, and $1 \mathrm{mM}$ EGTA and buffered to $\mathrm{pH} 7.1$ with $5 \mathrm{mM}$ Tris $\mathrm{HCl}$ (14). The osmolality of this medium after buffering was $255 \mathrm{mOsm} / \mathrm{kg} \mathrm{H}_{2} \mathrm{O}$.

Mito ( $2 \mathrm{mg}$ protein) were energized with the addition of $5 \mathrm{mM}$ K-succinate. After a short equilibration period $(\sim 30 \mathrm{~s})$, state 3 respiration was induced by the addition of $300 \mathrm{nmol}$ of ADP (Sigma Chemical Co., St. Louis, MO). After all of the added ADP had been phosphorylated to ATP, state 4 respiration was measured. The ratio of the $\mathrm{O}_{2}$ consumption in the presence of ADP (state 3) to that in its absence (state 4), termed the acceptor control ratio (ACR), was used as an indicator of the integrity of the Mito preparation. In addition, a matrix enzyme (fumarase) and a membrane enzyme (succinic Iodonitrotetrazolium reductase) were assayed by conventional techniques $(15,16)$.

Finally, maximal rates of $\mathrm{O}_{2}$ consumption were measured with the addition of $0.2 \mathrm{nmol}$ of FCCP (carbonyl cyanide $p$-trifluoromethoxyphenyl hydrasone (Sigma Chemical Co.), an uncoupler of oxidative phosphorylation.

\section{Mito $\mathrm{Ca}^{++}$handling studies}

Measurements of free $\mathrm{Ca}^{++}$movements were carried out in a waterjacketed reaction vessel by use of a $\mathrm{Ca}^{++}$sensitive electrode (Radiometer F2110) and a reference electrode (Radiometer $\mathrm{K} 401$ ) at $25^{\circ} \mathrm{C}$. The signal from the $\mathrm{Ca}^{++}$electrode was amplified through a Radiometer PHM $82 \mathrm{pH}$ meter (Radiometer America Inc., Westlake, $\mathrm{OH}$ ). The signals from the $\mathrm{O}_{2}$ electrode (monitored with a model $53 \mathrm{O}_{2}$ monitor [Yellow Springs Instrument Co.]) and the $\mathrm{pH}$ meter were both fed into a dual-channel strip-chart recorder (Linear Instruments Corp., Irvine, CA). The $\mathrm{Ca}^{++}$electrode was calibrated with $\mathrm{CaCl}_{2}$ standards added to each reaction medium as required, and the logarithmic response was linearized graphically. The incubation medium for $\mathrm{Ca}^{++}$ uptake and release experiments was the same as for the respiration studies with the omission of EGTA. Mito $(5 \mathrm{mg}$ protein) were suspended in a 3-ml incubation volume. The rate of $\mathrm{Ca}^{++}$uptake was measured in the presence of $66.7 \mu \mathrm{M} \mathrm{CaCl}_{2}$ and $5 \mathrm{mM} \mathrm{K}$-succinate. $\mathrm{Ca}^{++}$release was measured in the absence of added $\mathrm{CaCl}_{2}$ after the addition of $5 \mathrm{nmol}$ ruthenium red, an inhibitor of $\mathrm{Mito}^{\mathrm{Ca}^{++}}$exchange. Tissue and Mito $\mathrm{Ca}^{++}$content were measured by atomic absorption spectroscopy (model 370; Perkin Elmer Corp., Coleman Instruments Div., Oak Brook, IL).

\section{Biochemical analyses}

Inulin in plasma and urine was measured by autoanalyzer techniques. Plasma and urine sodium were measured by flame photometry (model 343; Instrumentation Laboratory Inc., Lexington, MA). Plasma and urine osmolality were measured by freezing point depression (model 312; Advanced Instruments, Inc., Needham Heights, MA).

\section{Calculations}

Inulin clearance to estimate GFR, as well as solute excretion and fractional excretion of sodium, were calculated by conventional formulae.

\section{Morphological studies}

After an infusion of NE for $40 \mathrm{~min}(n=4)$ or an infusion of $\mathrm{NE}+\mathrm{V}$ for $2 \mathrm{~h}(n=5)$, the kidneys were fixed $3 \mathrm{~h}$ after NE by intraaortic perfusion (17) of one-half strength Karnovsky's fixative buffered with potassium phosphate ( $\mathrm{pH}$ 7.4), at a perfusion pressure maintained equal to or slightly greater than mean arterial pressure. A total of $300-$ $400 \mathrm{ml}$ of fixative was used in each animal. This methodology has been previously used in this model (3).

Pieces of kidney from each animal were embedded in paraffin according to routine histologic methods. Sections $5 \mu \mathrm{m}$ thick were cut and stained with hematoxylin and eosin for light microscopic analysis.

Tissue for transmission electron microscopy was minced and

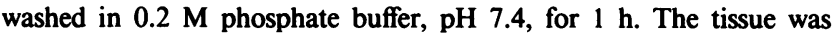
then postfixed in $2 \%$ osmium tetroxide buffered in $0.1 \mathrm{M} s$-collidine (pH 7.2-7.4) for $1 \mathrm{~h}$ at room temperature, stained en bloc with uranyl acetate in veronal acetate buffer at $\mathrm{pH} 5.0$, dehydrated in a graded series of alcohols, treated with propylene oxide, and embedded in epoxy resin. Ultrathin sections were cut on a Sorvall MT-2 ultramicrotome (E. I. Du Pont de Nemours \& Co., Inc., Sorvall Instruments Div., Newtown, CT), stained sequentially in $7.5 \%$ uranyl magnesium acetate and $0.15 \%$ lead citrate, and examined with a Siemens 102 transmission electron microscope (Siemens Mfg. Co. Inc., Freeberg, IL). Semithin epoxy sections (0.5-1.0 $\mu \mathrm{m}$ thick) also were cut, stained with toluidine blue, and viewed under a light microscope.

\section{Quantitation of structural alterations}

Paraffin sections were used for the quantitative analysis of injury. In each kidney, five areas each from the outer cortex, the midcortex, and the inner cortex were analyzed. The data from each region were then combined to give a single value for the outer cortical, midcortical, and inner cortical areas. Tubular injury was evaluated in the proximal tubule since it represented the major site of injury along the nephron. By means of a Leitz-Wetzlar overhead projector microscope (E. Leitz, Inc., Rockleigh, NJ), each area was first centered at low power magnification, and then the high power objective was positioned for viewing the field at random, without moving of the specimen stage to avoid bias of the chosen area. The image was projected upon a screen on to which 144 points had been inscribed. The cell or structure lying under or nearest each point was classified by one observer without the observer's having prior knowledge of the treatment given to the specimen being examined. Each of the counted proximal tubular cells was assigned to one of the following categories: $(a)$ normal when indistinguishable from controls; $(b)$ injured when the cell revealed no evidence of necrosis but the cell shape was obviously altered to a low cuboidal or squamous type or revealed extensive apical vesiculation or vacuolization in addition to the loss of brush border; or $(c)$ necrosis when the cell showed irreversible damage such as loss of membrane integrity or loss of nuclear staining.

\section{Statistical analyses}

All morphological results are expressed as mean \pm SEM.The $t$ test (two tailed) was used to evaluate the significance of differences between the different groups studied.

Where appropriate, linear regression analysis, analysis of variance and the $t$ test were used to determine significant differences among 


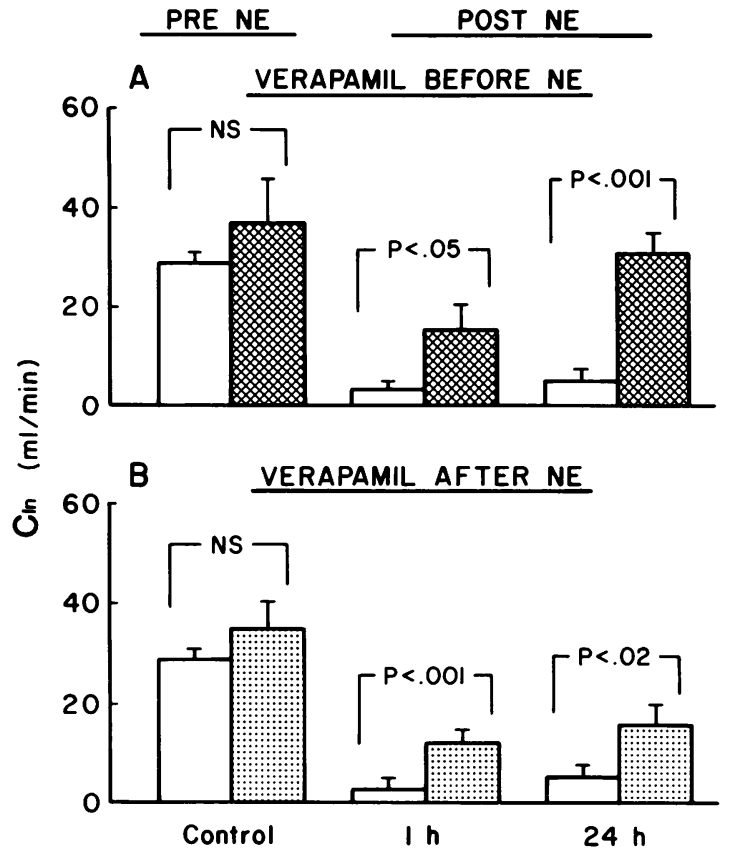

Figure 1. (A) $\mathrm{V}$ administered for $30 \mathrm{~min}$ before $\mathrm{NE}$ (cross-hatched bars, top) significantly attenuated the fall in inulin clearance $\left(\mathrm{C}_{\mathrm{In}}\right)$ induced by NE alone (open bars) both 1 and $24 \mathrm{~h}$ after NE. (B) V administered for $2 \mathrm{~h}$ after NE (stippled bars, bottom) also significantly attenuated the fall in $C_{\mathrm{In}}$ both 1 and $24 \mathrm{~h}$ after NE.

treatments and/or between animals. Significance was accepted at $P$ $<0.05$. All values reported represent mean \pm SEM.

\section{Results}

Effect of unilateral $V+N E$ or $N E+V$ on GFR (Fig. 1). Previously we reported that GFR is reduced 1,3 , and $24 \mathrm{~h}$ after NE in this model (1). The present results confirm those of the previous study; GFR at 1 and $24 \mathrm{~h}$ averaged $2.4 \pm 1.1$ and $5.0 \pm 2.0 \mathrm{ml} / \mathrm{min}$, respectively, in the $\mathrm{NE}$ alone group. Furthermore, it is clear that administration of unilateral, intrarenal $\mathrm{V}$ for $30 \mathrm{~min}$ before $\mathrm{NE}$, which did not increase GFR of either kidney during this period, protects GFR at both 1 and $24 \mathrm{~h}(15.0 \pm 5.5$ vs. $2.4 \pm 1.1 \mathrm{ml} / \mathrm{min}, P<0.05$, and $31.0 \pm 4.5$ vs. $5.0 \pm 2.0 \mathrm{ml} / \mathrm{min}, P<0.001$, respectively). It can also be seen that $\mathrm{V}$ infused after $\mathrm{NE}$ also exerts a substantial protective effect on GFR at 1 and $24 \mathrm{~h}(15.0 \pm 2.4$ vs $2.4 \pm 1.1$ $\mathrm{ml} / \mathrm{min}, P<0.001$, and $16.3 \pm 3.6$ vs. $5.0 \pm 2.0 \mathrm{ml} / \mathrm{min}, P$ $<0.02$, respectively). At $24 \mathrm{~h}, \mathrm{~V}$ administered for $30 \mathrm{~min}$ before NE was somewhat more effective in protecting GFR

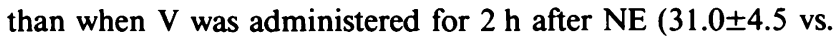
$16.3 \pm 3.6 \mathrm{ml} / \mathrm{min}, P<0.05)$.

Effect of unilateral $V+N E$ or $N E+V$ on $R B F$ (Table I). In the $\mathrm{NE}$ alone group, $\mathrm{RBF}$ was $220 \pm 25 \mathrm{ml} / \mathrm{min}$ before $\mathrm{NE}$ and was reduced to zero during $\mathrm{NE}$; $\mathrm{RBF}$ then recovered slowly after NE to $56 \mathrm{ml} / \mathrm{min}$ at $30 \mathrm{~min}$, and $72 \mathrm{ml} / \mathrm{min}$ at $45 \mathrm{~min}$, and it averaged $82 \pm 38 \mathrm{ml} / \mathrm{min} 1 \mathrm{~h}$ after NE $(P$ $<0.05$ as compared with control). $\mathrm{V}+\mathrm{NE}$ kidneys had an $\mathrm{RBF}$ at $1 \mathrm{~h}$, after NE which was somewhat higher $(162 \pm 32$ $\mathrm{ml} / \mathrm{min}$ ) and not different from control ( $P, \mathrm{NS})$. RBF was significantly higher at $1 \mathrm{~h}$ in the $\mathrm{NE}+\mathrm{V}$ group than in the NE alone group $(207 \pm 18$ vs. $82 \pm 38 \mathrm{ml} / \mathrm{min}, P<0.025)$.

Effect of unilateral $V+N E$ or $N E+V$ on solute excretion, urine flow, and fraction sodium excretion (Table I). $\mathrm{V}$ infused before NE increased solute excretion from $251 \pm 55$ to $546 \pm 63$ $\mathrm{mOsm} / \mathrm{min}(P<0.005) .1 \mathrm{~h}$ after NE in $\mathrm{V}+\mathrm{NE}$ animals, solute excretion averaged $111 \pm 30 \mathrm{mOsm} / \mathrm{min}$, a value not significantly different from that seen at $1 \mathrm{~h}$ in the NE alone group (101 $\pm 5 \mathrm{mOsm} / \mathrm{min})$. As described above, however, GFR was very low in the NE alone group and substantially improved in the $\mathrm{V}+\mathrm{NE}$ group. When $\mathrm{V}$ was infused after $\mathrm{NE}$ there was an immediate solute diuresis and solute excretion averaged $398 \pm 88 \mathrm{mOsm} / \mathrm{min}$ at $1 \mathrm{~h}$, a value significantly higher than that observed in both the NE alone group (101 \pm 5 $\mathrm{mOsm} / \mathrm{min})$ and in the $\mathrm{V}+\mathrm{NE}$ group $(111 \pm 30 \mathrm{mOsm} / \mathrm{min}$; both $P<0.005$ ).

$\mathrm{V}$ infused before NE increased urine flow from $0.19 \pm 0.06$ to $1.23 \pm 0.24 \mathrm{ml} / \mathrm{min}(P<0.001)$ and fractional sodium excre-

Table I. Effect of $V$ on RBF, Solute Excretion, Urine Flow, and FE $E_{N a}$ Before and After NE-induced Ischemia*

\begin{tabular}{|c|c|c|c|c|c|c|c|c|}
\hline & \multirow[b]{2}{*}{ Cont } & \multirow[b]{2}{*}{$\mathrm{V}$ alone } & \multicolumn{3}{|l|}{$1 \mathrm{~h}$ after $\mathrm{NE}$} & \multicolumn{3}{|c|}{$24 \mathrm{~h}$ after NE } \\
\hline & & & NE alone & $\mathrm{V}$ before $\mathrm{NE}$ & $V$ after NE & NE alone & $\mathrm{V}$ before $\mathrm{NE}$ & $\mathrm{V}$ after NE \\
\hline $\begin{array}{l}\mathrm{RBF}(\mathrm{ml} / \mathrm{min}) \\
\text { Solute excretion }\end{array}$ & $220 \pm 25$ & $319 \pm 38 \ddagger$ & $82 \pm 38 \ddagger$ & $162 \pm 32$ & $207 \pm 18 \S$ & ND & ND & ND \\
\hline $\begin{array}{l}(\mathrm{mOsm} / \mathrm{min}) \\
\text { Urine flow }\end{array}$ & $251 \pm 55$ & $546 \pm 63 \ddagger$ & $101 \pm 5 \ddagger$ & $111 \pm 30 \ddagger$ & $398 \pm 88 \S$ & $96 \pm 25 \ddagger$ & ND & $198 \pm 29 \S$ \\
\hline $\begin{array}{l}(\mathrm{ml} / \mathrm{min}) \\
\text { Fractional sodium }\end{array}$ & $0.19 \pm 0.06$ & $1.23 \pm 0.24 \ddagger$ & $0.05 \pm 0.02 \ddagger$ & $0.17 \pm 0.05 \S$ & $0.96 \pm 0.42 \ddagger \S$ & $0.18 \pm 0.05$ & $0.55 \pm 0.19$ & $0.34 \pm 0.08$ \\
\hline excretion (\%) & $1.20 \pm 0.46$ & $4.30 \pm 0.86 \ddagger$ & $2.86 \pm 1.10$ & $0.93 \pm 0.25$ & $8.0 \pm 2.0 \ddagger$ & $4.05 \pm 1.40$ & ND & $2.9 \pm 1.4$ \\
\hline
\end{tabular}

Cont, control; ND, not determined. * Mean \pm SE. $¥$ At least $P<0.05$ as compared with control. $\S$ At least $P<0.05$ as compared with NE alone at the same time or at least $P<0.05$ as compared with $\mathrm{V}$ before $\mathrm{NE}$ at the same time. 


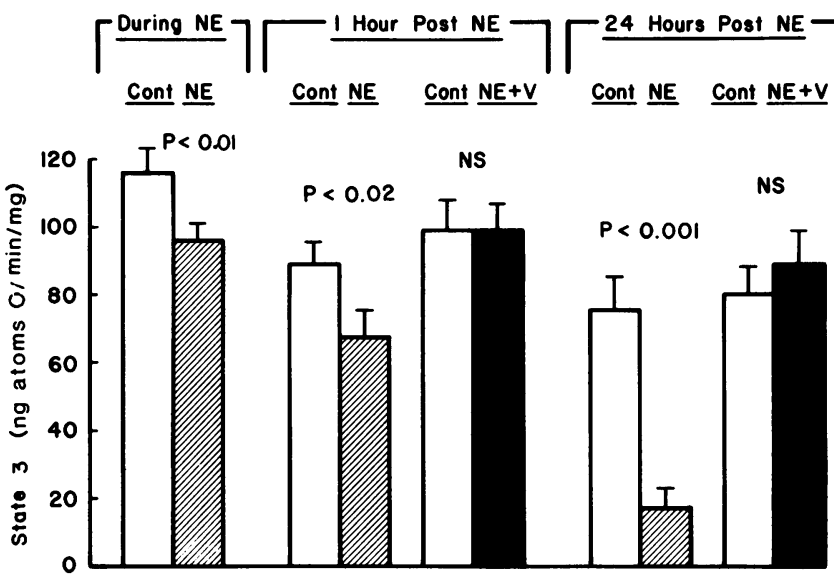

Figure 2. S3 respiration during and after NE infusion (hatched bars) decreased progressively. $\mathrm{V}$ infused after $\mathrm{NE}$ (solid bars) prevented the decrease in S3 at both 1 and $24 \mathrm{~h}$. Contralateral (Cont, control) kidneys are represented by open bars.

tion $\left(\mathrm{FE}_{\mathrm{Na}}\right)$ from $1.2 \pm 0.46$ to $4.30 \pm 0.86 \%(P<0.01)$. In dogs infused with $\mathrm{NE}$ alone, urine flow was low at $1 \mathrm{~h}(0.05 \pm 0.02$ $\mathrm{ml} / \mathrm{min}$ ) and $\mathrm{FE}_{\mathrm{Na}}$ averaged $2.86 \pm 1.10 \%$. The $\mathrm{V}+\mathrm{NE}$ group had a slightly higher urine flow at $1 \mathrm{~h}$ as compared with the $\mathrm{NE}$ alone group $(0.17 \pm 0.05$ vs. $0.05 \pm 0.02 \mathrm{ml} / \mathrm{min}, P<0.05)$; $\mathrm{FE}_{\mathrm{Na}}$ was not significantly different between the $\mathrm{V}$ $+\mathrm{NE}$ and $\mathrm{NE}$ alone groups $(0.93 \pm 0.25$ vs. $2.86 \pm 1.10 \%$, $P, \mathrm{NS})$.

$\mathrm{V}$ infused after $\mathrm{NE}$ resulted in a sustained increase in urine flow $(0.96 \pm 0.42 \mathrm{ml} / \mathrm{min})$ which was significantly higher than urine flow $((0.17 \pm 0.05 \mathrm{ml} / \mathrm{min})$ in the $\mathrm{V}+\mathrm{NE}$ group $(P$ $<0.05)$ and in the NE alone group $(0.05 \pm 0.02 \mathrm{ml} / \mathrm{min}, P$ $<0.025)$. $\mathrm{FE}_{\mathrm{Na}}$ was also acutely increased at $1 \mathrm{~h}$ in the $\mathrm{NE}$ $+\mathrm{V}$ group $(8.0 \pm 2.0 \%)$.
Mito respiration. There was a significant and steady decrease in state 3 respiration (S3) as reflow ensued in the NE alone kidneys (Fig. 2). As compared with control values for S3 of $116 \pm 7 \mathrm{ng}$ atoms $\mathrm{O} / \mathrm{min}$ per $\mathrm{mg}, \mathrm{S} 3$ at the end of the $\mathrm{NE}$ infusion, but before reflow, was slightly reduced, to $96 \pm 4 \mathrm{ng}$ atoms $\mathrm{O} / \mathrm{min}$ per $\mathrm{mg}, P<0.01$; after 1 and $24 \mathrm{~h}$ of reflow S3 had fallen to $67 \pm 7$ and $17 \pm 5 \mathrm{ng}$ atoms $O \mathrm{~min} / \mathrm{mg}$, respectively ( $P<0.02$ and $P<0.001$ as compared with control). V infused after NE prevented the decrease in $\mathrm{S} 3$ as compared with control at $24 \mathrm{~h}(86 \pm 9$ vs. $84 \pm 9 \mathrm{ng}$ atoms $\mathrm{O} / \mathrm{min}$ per $\mathrm{mg} ; P$, $\mathrm{NS})$ as well as at $1 \mathrm{~h}(105 \pm 6 \mathrm{vs}$. $102 \pm 9 \mathrm{ng}$ atoms $\mathrm{O} / \mathrm{min}$ per $\mathrm{mg} ; \boldsymbol{P}$, NS). Similar patterns of protection were observed in measurements of state 4 respiration (S4), uncoupled respiration, and ACR (ACR $=$ S3/S4) (Table II).

Mito and tissue $\mathrm{Ca}^{++}$. Mito $\mathrm{Ca}^{++}$was not increased during the 40-min NE infusion and before reflow (control 23.3 \pm 0.9 $\mathrm{nmol} / \mathrm{mg}$ Mito protein vs. NE $24.4 \pm 1.4 \mathrm{nmol} / \mathrm{mg}$ Mito protein) (Fig. 3). There was also no difference after $1 \mathrm{~h}$ of reflow. After $24 \mathrm{~h}$ of reflow, however, Mito $\mathrm{Ca}^{++}$increased (control 26.4 \pm 4.0 $\mathrm{nmol} / \mathrm{mg}$ Mito protein vs. NE $97.7 \pm 12.0 \mathrm{nmol} / \mathrm{mg}$ Mito protein, $P<0.01)$ in the NE alone group. In contrast, at 24 $\mathrm{h}$, Mito $\mathrm{Ca}^{++}$was no different from control in the $\mathrm{NE}+\mathrm{V}$ group ( $52.5 \pm 17.8$ vs. $51.1 \pm 12.1 \mathrm{nmol} / \mathrm{mg}$ Mito protein).

It is important to recognize that the comparisons made were between Mito $\mathrm{Ca}^{++}$content of contralateral (control) and ischemic kidneys. This seems to be the most appropriate comparison since renal cortical tissue $\mathrm{Ca}^{++}$content in mongrel dogs may vary substantially even in control kidneys (Table III). The variability probably reflects the nonhomogeneous nature of mongrel dogs and differs appreciably from our observations of renal cortical tissue $\mathrm{Ca}^{++}$levels in normal laboratory rats (unpublished observations). $\mathrm{V}$ and $\mathrm{N}$ also abolished the renal cortical tissue $\mathrm{Ca}^{++}$accumulation at $24 \mathrm{~h}$ after NE (Table III).

Table II. Effect of V on S4, Uncoupled Respiration, and ACR During and After NE Infusion*

\begin{tabular}{|c|c|c|c|c|c|c|c|c|c|c|}
\hline & \multirow[b]{2}{*}{ Cont } & \multirow[b]{2}{*}{ During NE } & \multicolumn{4}{|l|}{ I h after $\mathrm{NE}$} & \multicolumn{4}{|l|}{$24 \mathrm{~h}$ after NE } \\
\hline & & & Cont & NE alone & Cont & $\mathbf{N E}+\mathbf{V}$ & Cont & NE alone & Cont & $\mathrm{NE}+\mathrm{V}$ \\
\hline $\begin{array}{l}\text { S4 (ng atoms } \\
\text { 0/min per } \mathrm{mg} \\
\text { mito protein) }\end{array}$ & $23.0 \pm 1.0$ & $23.0 \pm 0.9$ & $18.0 \pm 1.0$ & $17.0 \pm 1.3$ & $19.0 \pm 1.7$ & $20.0 \pm 1.4$ & $16.0 \pm 1.2$ & $7.0 \pm 1.1$ & $17.0 \pm 0.8$ & $17.0 \pm 0.4$ \\
\hline$P$ value & \multicolumn{2}{|c|}{ NS } & \multicolumn{2}{|c|}{ NS } & \multicolumn{2}{|c|}{ NS } & \multicolumn{2}{|c|}{$<0.001$} & \multicolumn{2}{|c|}{ NS } \\
\hline $\begin{array}{l}\text { Uncoupled (ng } \\
\text { atoms } 0 / \text { min per } \\
\text { mg mito protein) }\end{array}$ & $182.0 \pm 8.0$ & $184.0 \pm 10.0$ & $137.0 \pm 17.0$ & $118.0 \pm 20.0$ & \multicolumn{6}{|c|}{ Uncoupled (ng } \\
\hline$P$ value & \multicolumn{2}{|c|}{ NS } & \multicolumn{2}{|c|}{$<0.05$} & \multicolumn{2}{|c|}{ NS } & \multicolumn{2}{|c|}{$<0.001$} & \multicolumn{2}{|c|}{ NS } \\
\hline ACR $(S 3 / S 4)$ & $5.10 \pm 0.24$ & $4.12 \pm 0.17$ & $4.87 \pm 0.28$ & $3.86 \pm 0.21$ & $5.24 \pm 0.35$ & $5.15 \pm 0.32$ & $4.75 \pm 0.39$ & $2.09 \pm 0.36$ & $4.63 \pm 0.46$ & $5.36 \pm 0.44$ \\
\hline$P$ value & \multicolumn{2}{|c|}{$<0.005$} & \multicolumn{2}{|c|}{$<0.005$} & \multicolumn{2}{|c|}{ NS } & \multicolumn{2}{|c|}{$<0.001$} & \multicolumn{2}{|c|}{$<0.05$} \\
\hline
\end{tabular}

Uncoupled, during FCCP. Cont, contralateral control kidney. * Mean \pm SE. Variations among dogs accounts for some differences in control kidney values at different times. 


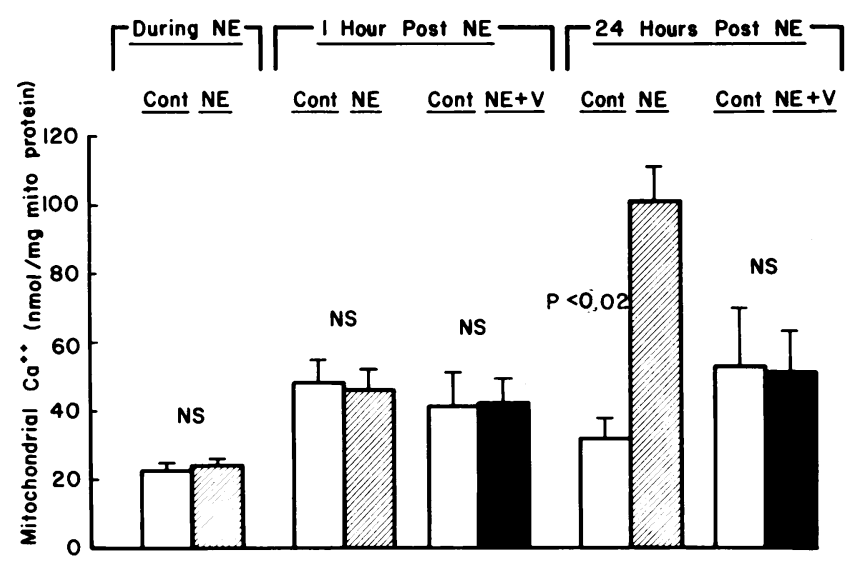

Figure 3. Mito $\mathrm{Ca}^{++}$content (hatched bars) was substantially increased at $24 \mathrm{~h}$. V infused after NE (solid bars) prevented the increase in Mito $\mathrm{Ca}^{++}$content at $24 \mathrm{~h}$.

Mito $\mathrm{Ca}^{++}$uptake rate (Fig. 4) during NE before reflow was no different from control $(357 \pm 26$ vs. $371 \pm 17 \mathrm{nmol} / \mathrm{min}$ per mg; $P$, NS). No decrease in $\mathrm{Ca}^{++}$uptake was observed after $1 \mathrm{~h}$ of reflow. However, a significant decrease $(P<0.005)$ in $\mathrm{Ca}^{++}$uptake was observed at $24 \mathrm{~h}(34 \pm 17$ vs. $167 \pm 33$ $\mathrm{nmol} / \mathrm{min}$ per $\mathrm{mg}$ ) in the $\mathrm{NE}$ alone group. $\mathrm{V}$ infused after NE prevented this decrease in $\mathrm{Ca}^{++}$uptake rate at $24 \mathrm{~h}(335 \pm 21$ vs. $349 \pm 13 \mathrm{nmol} / \mathrm{min}$ per $\mathrm{mg}$; NS).

Mito $\mathrm{Ca}^{++}$release rate (Fig. 5) was not affected by $\mathrm{NE}$ infusion as compared with control until $24 \mathrm{~h}$ of reflow, when $\mathrm{Ca}^{++}$release had increased dramatically to $23.0 \pm 7.2 \mathrm{nmol} /$ min per $\mathrm{mg}(P<0.05)$. The $\mathrm{Ca}^{++}$release rate in the $\mathrm{NE}+\mathrm{V}$ group did not increase as compared with control. The increase in Mito $\mathrm{Ca}^{++}$release $24 \mathrm{~h}$ after the ischemic insult may be due to endogenous Mito $\mathrm{Ca}^{++}$content, diminished electromotive force across the inner Mito membrane, or the presence of increased permeability through ruthenium red insensitive channels.

Effects of $N E+N$ at $24 h$. In Table IV are listed the effects of $\mathrm{NE}+\mathrm{N}$ on renal and Mito function at $24 \mathrm{~h}$ as compared with the contralateral, control kidneys. $\mathrm{N}$ infused intrarenally for $2 \mathrm{~h}$ after NE also protects renal and Mito function to a degree similar to that seen with $\mathrm{V}$.

Mito enzymes. The concentration of both the matrix enzyme (fumarase) and the inner membrane enzyme (succinic INT reductase) were similar in Mito pellets from NE-treated kidneys, control kidneys, and V-treated kidneys $1 \mathrm{~h}$ after NE. Control, NE alone, and V-treated Mito fumarase levels averaged $2.72 \pm 0.18,3.04 \pm 0.28$, and $2.23 \pm 0.03 \Delta \mathrm{OD} / \mathrm{min}$ per mg Mito protein (all $P, \mathrm{NS}$ ), respectively; succinate-Iodonitrotetrazolium reductase levels averaged $0.66 \pm 0.04,0.67 \pm 0.02$, and $0.58 \pm 0.04$ $\Delta \mathrm{OD} / \mathrm{min}$ per $\mathrm{mg}$ Mito protein $(P, \mathrm{NS})$, respectively. These results suggest that comparable amounts of Mito were harvested from control, NE-treated, and V-treated kidneys. The differences in Mito respiration indicate that both normal and damaged Mito were harvested. The differences in Mito dysfunction would be even greater if normal Mito were preferentially harvested; we, however, have no evidence for this in the present study or in previous studies in the rat (18).

Morphological analysis of protection in $N E+V$-treated dogs. In Table $\mathrm{V}$ are listed the comparative effects of $\mathrm{NE}$ alone or $\mathrm{NE}+\mathrm{V}$ on the percentage of normal, injured, and necrotic tubules in dog kidneys $3 \mathrm{~h}$ after NE. Similar degrees of injured and necrotic cells were seen in outer, mid, and inner cortex ( $\sim 50$ and $5 \%$, respectively). $\mathrm{V}$ infused for $2 \mathrm{~h}$ after ischemia dramatically reduced these levels approximately 10 -fold $(\sim 8$ and $0.5 \%$, respectively). Both light and transmission electron microscopy also demonstrate substantial protection in $\mathrm{V}$ treated dogs (Fig. 6).

\section{Discussion}

The present results demonstrate that the CEBs, $\mathrm{V}$ and $\mathrm{N}$, provide functional protection against NE-induced ischemic ARF in the dog. The protection was demonstrable when $\mathrm{V}$ was administered for $30 \mathrm{~min}$ before or for $2 \mathrm{~h}$ after the NEinduced ischemia. Protection was also observed when $\mathrm{N}$ was infused for $2 \mathrm{~h}$ after NE. Although RBF, as assessed by flow meter, the paleness of the kidney, and the collapsed peritubular

Table III. Comparison of Renal Cortical Tissue $\mathrm{Ca}^{++}$Content (mmol/kg dry wt) in Dogs*

\begin{tabular}{|c|c|c|c|c|c|c|}
\hline & \multicolumn{3}{|l|}{$\mathrm{NE}$ alone } & \multicolumn{2}{|l|}{$\mathrm{NE}+\mathrm{V}$} & \multirow{2}{*}{$\begin{array}{l}\mathrm{NE}+\mathrm{N} \\
24 \mathrm{~h} \\
(n=4)\end{array}$} \\
\hline & $\begin{array}{l}\text { During } \\
(n=9)\end{array}$ & $\begin{array}{l}1 \mathrm{~h} \\
(n=9)\end{array}$ & $\begin{array}{l}24 \mathrm{~h} \\
(n=6)\end{array}$ & $\begin{array}{l}1 \mathrm{~h} \\
(n=7)\end{array}$ & $\begin{array}{l}24 \mathrm{~h} \\
(n=6)\end{array}$ & \\
\hline Control kidney & $8.2 \pm 0.67$ & $21.2 \pm 4.0$ & $11.9 \pm 1.3$ & $23.6 \pm 9.7$ & $23.6 \pm 9.7$ & $16.1 \pm 6.4$ \\
\hline Ischemic kidney & $8.1 \pm 1.1$ & $25.4 \pm 5.8$ & $45.3 \pm 11.0$ & $25.6 \pm 8.4$ & $24.9 \pm 11.5$ & $30.1 \pm 10.8$ \\
\hline$P$ value & NS & NS & $<0.05$ & NS & NS & NS \\
\hline
\end{tabular}

* Mean \pm SE. 


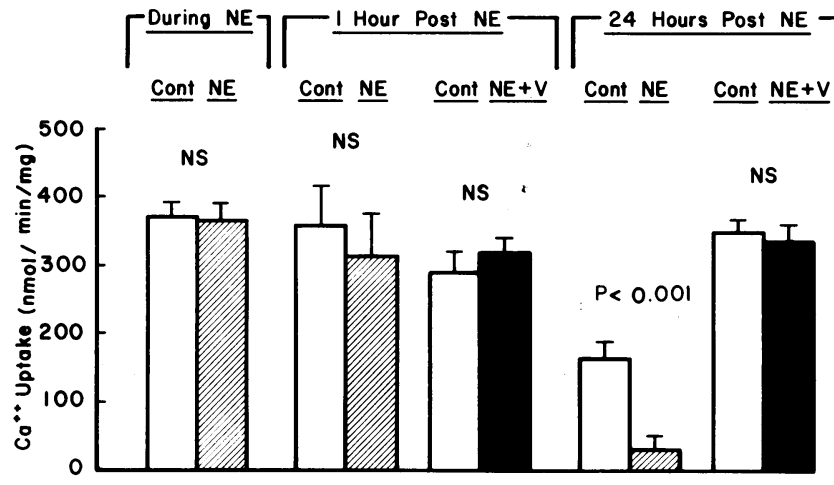

Figure 4. Mito $\mathrm{Ca}^{++}$uptake (hatched bars) was decreased $24 \mathrm{~h}$ after NE. $\mathrm{V}$ infused after NE (solid bars) prevented the decrease in Mito $\mathrm{Ca}^{++}$uptake $24 \mathrm{~h}$ after NE.

capillaries which prevented micropuncture measurements of vascular pressures, appeared to be absent during the NE infusion in the animals pretreated for $30 \mathrm{~min}$ with $\mathrm{V}$, an undetectably small preservation of RBF could not be totally excluded in those experiments. However, since significant protection was also demonstrable when $\mathrm{V}$ or $\mathrm{N}$ was administered after NE ischemia, the preservation of RBF during the ischemic insult can be excluded as a necessary factor accounting for the observed protection. This observation is important since, although at least three groups (19-21) have now confirmed our preliminary observation (22) that $\mathrm{V}$ administration before an ischemic insult affords protection against ischemic injury as assessed by preservation of GFR, two of these groups $(19,20)$ have failed to demonstrate protection when $\mathrm{V}$ is administered after the insult. In one study in which ischemia was produced by renal artery clamping for $70 \mathrm{~min}$ in the rat,

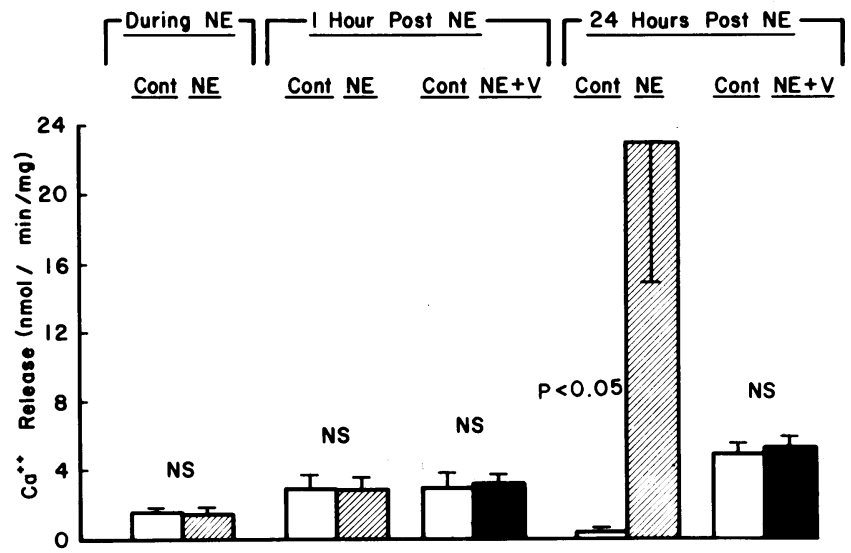

Figure 5. Mito $\mathrm{Ca}^{++}$release (hatched bars) was increased $24 \mathrm{~h}$ after NE. $V$ infused after NE (solid bars) prevented the increase in Mito $\mathrm{Ca}^{++}$release $24 \mathrm{~h}$ after NE.
Table IV. Effect of $N$ Infused for $2 h$ after $N E$ on Renal and Mito Function at $24 h(n=4) *$

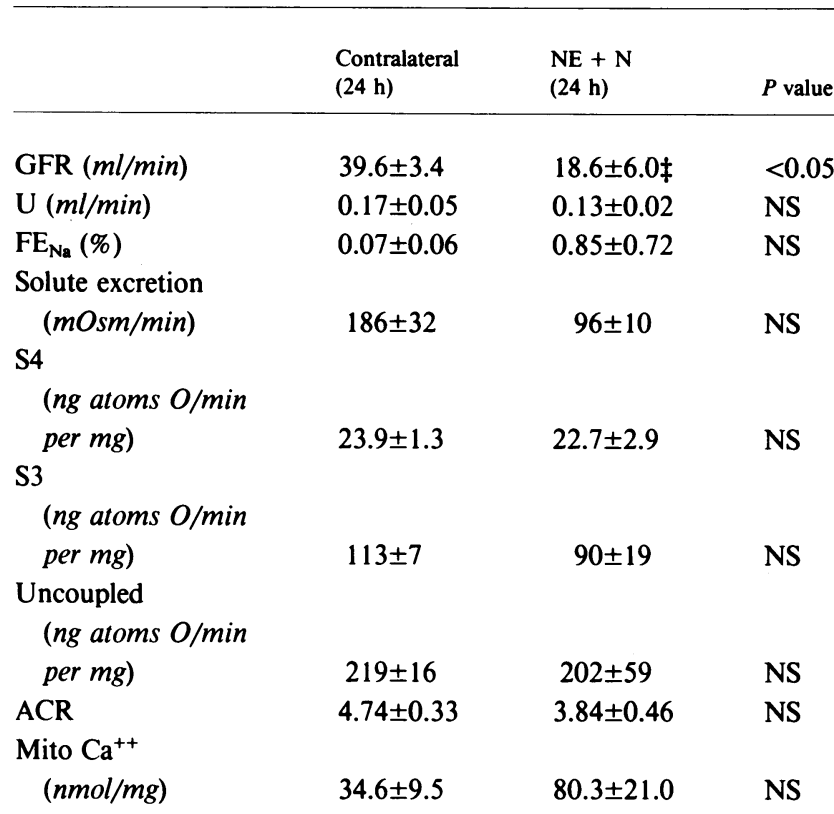

$U$, urine flow rate; uncoupled, during FCCP.

* Mean \pm SEM.

$¥$ This value was significantly increased as compared with the inulin clearance $24 \mathrm{~h}$ after NE in the absence of a CEB $(5.0 \pm 2.0$ vs. $18.6 \pm 6.0 \mathrm{ml} / \mathrm{min}, P<0.02$ ). Thus, $\mathrm{N}$ afforded significant functional and Mito protection. $\mathrm{V}$ at this dose is, however, somewhat more protective to Mito function than is $\mathrm{N}$.

the $\mathrm{V}$ was infused systemically for only $15 \mathrm{~min}$ after the insult, and no effect on GFR was observed after $24 \mathrm{~h}$ (19). In the other study, also in the rat, the 40-min intrarenal NE infusion was followed by a 2-h intrarenal infusion of $\mathrm{V}$, and no protection was observed (20). It is difficult to reconcile these negative results with those of the present study. It is clear, however, that this latter model in the rat differs from previous dog or rat studies with respect to the recovery of RBF after NE. Specifically, the RBF recovered to almost normal levels within $20 \mathrm{~min}(20)$, whereas we $(1,3)$ and others $(2,5,6)$ have reported that $\mathrm{RBF}$ recovery is usually quite slow after NE. Whereas most other investigators have used pentobarbital as the anesthetic while studying renal ischemia induced by NE $(1-6,23)$, the latter group (20) used inactin. Inactin, but not pentobarbital, is known to disrupt renal autoregulation in the rat (24).

Thus, differences among species, the chemical versus mechanical nature of the ischemic insult, the route of administration, and the amount and duration of the infusion postischemia may be very important factors in modulating the protective 
Table V. Morphometric Analysis of Normal, Injured, and Necrotic Tubules in NE Alone and NE + V-treated Animals 3 h After NE*

\begin{tabular}{|c|c|c|c|c|c|c|c|c|c|}
\hline & \multicolumn{3}{|c|}{ Outer cortex (\%) } & \multicolumn{3}{|c|}{ Mid cortex (\%) } & \multicolumn{3}{|c|}{ Inner cortex $(\%)$} \\
\hline & Normal & Injured & Necrotic & Normal & Injured & Necrotic & Normal & Injured & Necrotic \\
\hline $\mathrm{NE}(n=4)$ & $41.5 \pm 7.7$ & $53.1 \pm 8.4$ & $5.3 \pm 2.3$ & $34.3 \pm 5.3$ & $59.7 \pm 6.8$ & $6.0 \pm 2.7$ & $42.8 \pm 5.7$ & $55.2 \pm 5.6$ & $2.1 \pm 0.9$ \\
\hline $\mathrm{NE}+\mathrm{V}(n=5)$ & $93.0 \pm 3.6$ & $4.8 \pm 1.7$ & $0.2 \pm 0.2$ & $90.1 \pm 3.8$ & $8.9 \pm 3.5$ & $0.6 \pm 0.3$ & $91.3 \pm 3.0$ & $8.5 \pm 3.0$ & $0.1 \pm 0.1$ \\
\hline$P$ value & $<0.001$ & $<0.001$ & $<0.05$ & $<0.001$ & $<0.001$ & NS & $<0.001$ & $<0.001$ & NS \\
\hline
\end{tabular}

Necrosis is seldom seen at $1 \mathrm{~h}$ in this model and therefore studies were done $3 \mathrm{~h}$ postischemia. ${ }^{*}$ Mean $\pm \mathrm{SE}$.

effect of CEBs. Specifically, in the present study $\mathrm{V}$ and $\mathrm{N}$ were administered intrarenally to avoid any extrarenal peripheral vasodilation and reflex renal vasoconstriction that could occur and diminish renal perfusion during systemic administration of $\mathrm{V}$. Second, the duration of the intrarenal $\mathrm{V}$ infusion postischemia also appears to be quite important. In this regard, preliminary experiments in our laboratory demonstrated that a 1-h infusion of $\mathrm{V}$ postischemia, although able to improve renal function transiently at $1 \mathrm{~h}$, was insufficient to provide functional protection $24 \mathrm{~h}$ postischemia (unpublished results). In the present study a 2-h infusion of either $\mathrm{V}$ or $\mathrm{N}$ was clearly protective when renal function was evaluated $24 \mathrm{~h}$ after ischemia. Moreover, even the much longer $(2 \mathrm{~h})$ duration of the intrarenal CEB after the ischemia failed to provide the level of preservation of GFR observed with $\mathrm{V}$ pretreatment for 30 min. Thus, the protective effect of the CEB relates also, at least in part, to the relative proximity of the ischemic result. The protective effect of $\mathrm{V}$ against the ischemic insult is demonstrable not only in NE-induced ARF in the dog but also in the mechanical occlusion model as well. Wait et al. (25) have demonstrated significant protection of renal function in dogs given intrarenal $\mathrm{V}$ after a 1-h renal ischemic insult induced by mechanical occlusion of the renal artery.

Since micropuncture studies have demonstrated that NEinduced ARF involves an early (initiation) vasoconstrictor and a later (maintenance) tubular obstruction phase, without evidence of tubular back-leak $(1,6)$, the protective efficacy of the CEB must be considered on this background. There seems little doubt now that hormone-mediated vasoconstriction involves enhanced $\mathrm{Ca}^{++}$movement into smooth muscle cells (26). Recent in vivo studies in the conscious rat have demonstrated that two chemically dissimilar CEBs, $\mathrm{V}$ and $\mathrm{N}$, abolish the pressor and renal vasoconstrictor responses to NE, angiotensin, and vasopressin (7). It thus seems quite likely that a component of the protective effect of the CEBs, $\mathrm{V}$ and $\mathrm{N}$, involves attenuation of the postischemia renal vasoconstriction. In this regard, during the initiation phase ( $1 \mathrm{~h}$ after NE) of the ARF both the pre- and postinsult $\mathrm{V}$ studies were associated with higher RBF as compared with the animals infused with $\mathrm{NE}$ alone. There is, however, considerable evidence that makes it unlikely that the vascular effect of $\mathrm{V}$ constitutes the only component of the agent's protective effect. For example, $\mathrm{V}$ or isotonic saline infused intrarenally after renal ischemia increased RBF to nearly normal levels within $30 \mathrm{~min}$; only $\mathrm{V}$, however, exerts functional protection (25). We have also reported that RBF after NE recovered at a similar rate in mannitol-treated, polyethylene glycol-treated and hypertonic saline-treated dogs (23). Nevertheless, protection against ischemia-induced functional impairment was observed in the mannitol-treated and polyethylene glycol-treated dogs but not in the hypertonic saline-treated dogs (23). Finally, Williams et al. (27) reported that after mechanical occlusion of the renal artery for $60 \mathrm{~min}$, $\mathrm{RBF}$ in the dog recovers to $164 \%$ of preischemic levels within 5 min after release of the clamp and remains at this level for at least $30 \mathrm{~min}$. No protection of GFR was, however, observed $18 \mathrm{~h}$ later. Thus, recovery of renal function after ischemic injury does not depend upon whether RBF, and corresponding oxygen delivery, improves quickly $(6,23,25,27)$ or slowly $(1-6,23)$. Nevertheless, it is possible that an as yet undiscovered effect of $V$ on intrarenal $R B F$ redistribution or specific regional vascular sites might contribute to improved recovery from ischemic injury. Other agents such as furosemide (4) and mannitol $(1,3)$, which produce somewhat less or, at most, no greater renal vasodilation than does acetylcholine (4) or secretin (5), have been found to be very potent protective agents against this form of ischemic ARF. An assessment of several protective agents led to the proposal that the rate of solute excretion, as an index of intratubular pressure and flow rate, is also an important variable in the protection against ischemic ARF. Results of micropuncture studies (1) supported this proposal since early $(1 \mathrm{~h})$ after the ischemic insult, dogs pretreated with mannitol exhibited significantly higher intratubular pressures than did untreated animals $(31$ vs. $16 \mathrm{mmHg}$; $P<0.001$ ). Moreover, tubular microperfusion studies (1) demonstrated the presence of tubular obstruction in the untreated but not mannitol treated animals. These results led to the conclusion that both renal vasodilation and prevention of secondary tubular obstruction are necessary components in the prevention of ischemic ARF. This conclusion provided an explanation for the efficacy of mannitol and furosemide in protecting against ischemic ARF as well as for the failure of secretin or acetylcholine to offer protection, since either no, or 

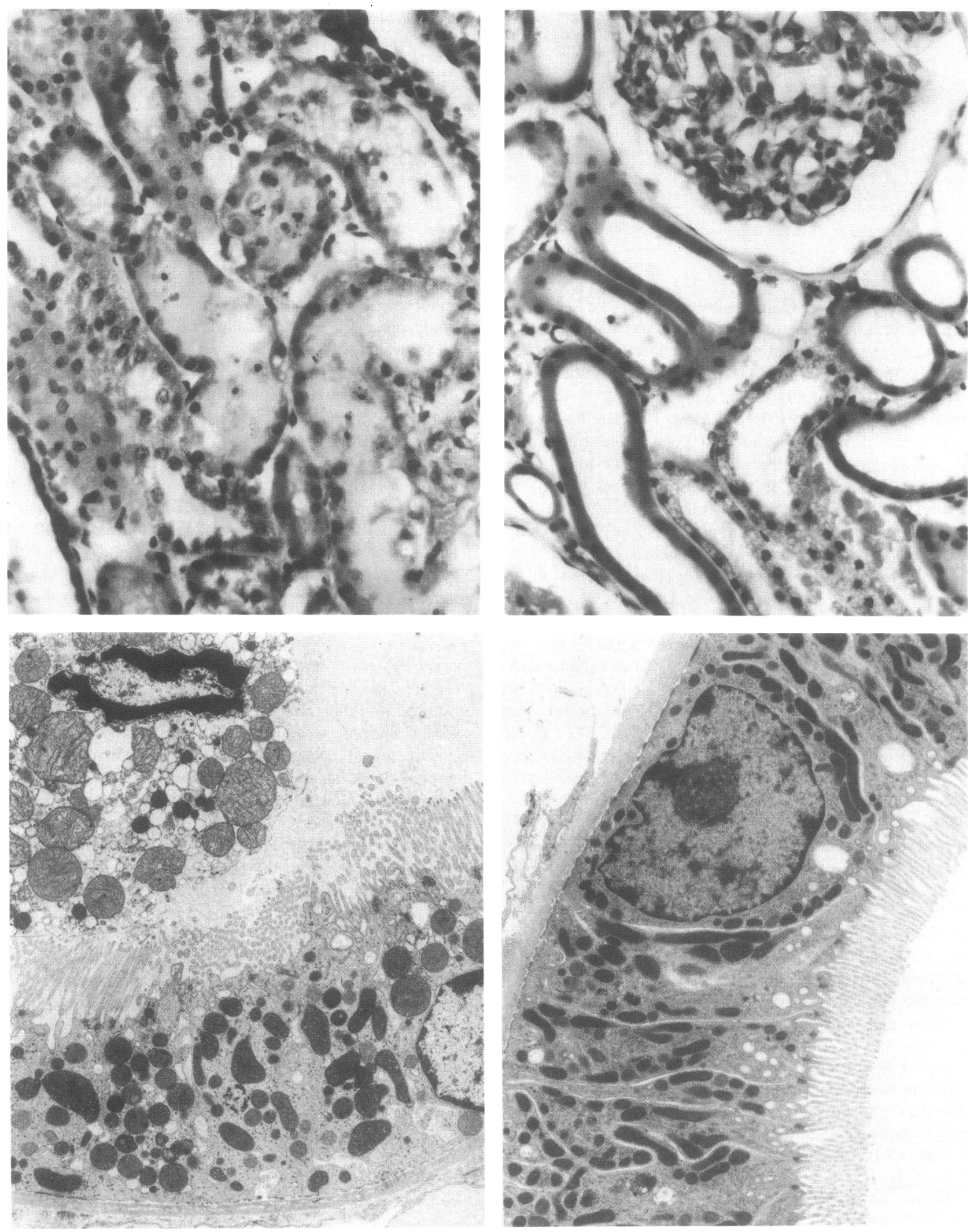
a very modest, solute diuresis was observed with the latter two agents. Taken together, these results suggest that factors in addition to vascular events are involved in the protective effect of $\mathrm{V}$. Moreover, since the induced solute diuresis by $\mathrm{V}$ and $\mathrm{N}$ is substantially less than observed in the mannitol $(1,2)$ and furosemide (4) studies, factors other than the rate of solute excretion must be invoked. The results in the present study suggest that the additional protective factor might be some event that occurs at the cellular level.

Substantial evidence for an effect of $\mathrm{V}$ on epithelium has been provided by several other studies. In dogs in which an aortic clamp was used to lower renal perfusion pressure within the autoregulation range, the intrarenal infusion of $\mathrm{V}$ did not increase RBF but a solute diuresis was still observed, and recollection micropuncture studies demonstrated a depressed proximal reabsorption (9). These in vivo studies of course do not exclude small changes in GFR or intrarenal blood flow distribution as being what accounts for the solute diuresis. $\mathrm{V}$ had, however, also been shown in vitro to exert an effect on toad bladder epithelium $(28)$ and on normal $(29,30)$ and anoxic (31) rabbit isolated proximal tubules.

In the present study the CEBs demonstrated substantial protection of Mito function as assessed by cellular respiration and calcium kinetics in vitro. It would appear that some cellular event is protected from ischemic injury by $\mathrm{V}$ and $\mathrm{N}$ administration. This conclusion is supported by the protective effect of these agents on the morphological appearance of the proximal tubules. The Mito studies provided important information about the subcellular events involved in the pathogenesis and prevention of this variety of ischemic ARF. In the untreated animals an increase in Mito $\mathrm{Ca}^{++}$content, a decrease in active $\mathrm{Ca}^{++}$uptake rate by Mito, and an increase in Mito $\mathrm{Ca}^{++}$release rate were observed $24 \mathrm{~h}$ after the ischemic insult. These findings are compatible with death of tubular epithelial cells as demonstrated functionally by diminished Mito respiration in the present study and the morphological presence of tubular necrosis both $3 \mathrm{~h}$ (present study) and $24 \mathrm{~h}$ after NE (3). It seems reasonable to suggest that this cell death provided the debris necessary for the development of the observed tubular obstruction. If, as suggested by Farber (8) and Trump et al. (32), Mito $\mathrm{Ca}^{++}$overload is not only the result of cell death but is also involved in the progressive deterioration of cell viability after ischemia, then a CEB such as $\mathrm{V}$ or $\mathrm{N}$ might be expected to attenuate these findings.

In the present studies it was clear that Mito $\mathrm{Ca}^{++}$overload did not occur during the ischemic period. This is not unexpected since the absence of active Mito proton extrusion during ischemia would abolish the electromotive driving force across the Mitro inner membrane, which is necessary for active $\mathrm{Ca}^{++}$ uptake by Mito and retention of $\mathrm{Ca}^{++}$within Mito (33). Furthermore, in animals treated with $\mathrm{NE}$ alone, Mito $\mathrm{Ca}^{++}$ loading was not observed in the first hour of reflow, when Mito respiration was diminished. This result in the dog clearly indicates that the early Mito dysfunction is probably a direct consequence of the ischemic insult rather than any consequence of increased Mito calcium concentration. Increases in Mito $\mathrm{Ca}^{++}$have, however, been observed in the rat $1 \mathrm{~h}$ after ischemia induced by renal artery clamping $(11,18,34,35)$, and these increases might reflect the more rapid return of RBF in this model of ARF. In the present study, however, a correlation between decreased Mito respiration and $\mathrm{Mito} \mathrm{Ca}^{++}$overload at $1 \mathrm{~h}$ cannot be invoked. Since $1 \mathrm{~h}$ postischemia the $\mathrm{RBF}$ and GFR were enhanced by $\mathrm{V}$, the $\mathrm{Ca}^{++}$load to the tubular epithelium was even greater in these animals than in those receiving no treatment, yet the Mito $\mathrm{Ca}^{++}$content was no higher than in contralateral (control) kidneys at $1 \mathrm{~h}$.

The V- and N-treated animals demonstrated profound differences in Mito $\mathrm{Ca}^{++}$and respiration as compared with the untreated animals. The progressive rise in $\mathrm{Mito}^{\mathrm{Ca}^{++}}$and deterioration in Mito respiration observed in the kidneys with ischemic ARF were totally abolished by the administration of $\mathrm{V}$ and $\mathrm{N}$, as were the abnormalities in Mito $\mathrm{Ca}^{++}$uptake and release. Thus, CEBs provided protection not only against the functional, but also against the Mito, injury. This functional and Mito protection against the ischemic insult was also accompanied by prevention of the morphological changes of tubular necrosis. These findings are therefore compatible with the hypothesis (36-40) that $\mathrm{Ca}^{++}$overload of tissue and Mito during reflow is an important factor in the progression of ischemic injury to cell death. CEBs therefore may exert a protective effect not only against renal vasoconstriction but also against the renal tubular necrosis after an ischemic insult. In the absence of tubular necrosis the cellular debris necessary for tubular obstruction and thus the maintenance phase of ischemic ARF may not be present. Moreover, attenuation of the renal vasoconstriction may prevent the lodging of any cellular debris that may result even in the presence of CEBs. Last, the fact that CEBs when administered after the ischemic insult were relatively more effective in protecting against the Mito dysfunction than in preserving GFR may suggest that factors in addition to cellular $\mathrm{Ca}^{++}$are involved in ischemic ARF.
Figure 6. (Upper left) Light micrograph from a dog that had received $\mathrm{NE}$ for $\mathbf{4 0} \mathrm{min} 3 \mathrm{~h}$ before sacrifice. Note the cell injury and necrosis present in the epithelium of the proximal tubule. $\times 380$. (Upper right) Light micrograph from a dog that had received $\mathrm{V}$ in addition to NE. The proximal tubular epithelial cells show normal structure. The normal proximal pars recta epithelium contains numerous lipid droplets. $\times 420$. (Lower left) Electron micrograph from a dog that had received NE for $40 \mathrm{~min} 3 \mathrm{~h}$ before sacrifice. The proximal tubular cells show early injury with simplication of cell shape and rounding of the Mito. Necrotic debris is seen in the lumen of the tubule. $\times 6,700$. (Lower right) Electron micrograph from a dog that had received $\mathrm{V}$ in addition to NE. Note the normal appearance of the proximal tubular epithelium. $\times 6,700$. 


\section{Acknowledgments}

The authors thank Ms. Linda M. Benson for excellent secretarial support, Mrs. Carolyn Burke for the illustrations used in this study, Mrs. Abby Erickson for performing the renal clearance and electrolyte measurements, and Dr. Allen Alfrey and Ms. Nancy Miller for performing the atomic absorption measurements of tissue and Mito $\mathrm{Ca}^{++}$.

This study was supported in part by grants AM25151 and AM19928 from the National Institutes of Health and contract DAMD17-83-C3146 from the Department of the Army.

\section{References}

1. Burke, T. J., R. E. Cronin, K. L. Duchin, L. N. Peterson, and R. W. Schrier. 1980. Ischemic and tubular obstruction during acute renal failure in dogs: mannitol in protection. Am. J. Physiol. 238(Renal Fluid Electrolyte Physiol. 7):F305-F314.

2. Mauk, R. H., R. V. Patak, S. Z. Fadem, M. D. Lifschitz, and J. H. Stein. 1977. Effect of prostaglandin $E$ administration in a nephrotoxic and a vasoconstrictor model of acute renal failure. Kidney Int. 12:122-130.

3. Cronin, R. E., A. de Torrente, P. D. Miller, R. E. Bulger, T. J. Burke, and R. W. Schrier. 1978. Pathogenetic mechanisms in early norepinephrine-induced acute renal failure: functional and histological correlates of protection. Kidney Int. 14:115-125.

4. de Torrente, A., P. D. Miller, R. E. Cronin, P. E. Paulsen, A. L. Erickson, and R. W. Schrier. 1978. Effects of furosemide and acetylcholine in norepinephrine-induced acute renal failure. Am. J. Physiol. 235:F131-F136.

5. Patak, R. V., S. Z. Fadem, M. D. Lifschitz, and J. H. Stein. 1979. Study of factors which modify the development of norepinephrineinduced acute renal failure in the dog. Kidney Int. 15:227-237.

6. Conger, J. D., J. B. Robinette, and S. J. Guggenheim. 1981. Effect of acetylcholine on the early phase of reversible norepinephrineinduced acute renal failure. Kidney Int. 19:399-409.

7. Goldberg, J. P., and R. W. Schrier. 1984. Effect of calcium membrane blockers on in vivo vasoconstrictor properties of norepinephrine, angiotensin II and vasopressin. Miner. Electrolyte Metab. 10:178-183.

8. Farber, J. L. 1981. Mini review: the role of calcium in cell death. Life Sci. 29:1289-1295.

9. McCrorey, H. L., T. Berl, T. J. Burke, A. de Torrente, and R. W. Schrier. 1980. Effect of calcium transport inhibitors in renal hemodynamics and electrolyte excretion in the dog. In Hormonal Regulation of Sodium Excretion. B. Lichardus, R. W. Schrier, and J. Ponce, editors. Elsevier/North Holland Biomedical Press, New York. 113-120.

10. Burke, T. J., P. E. Arnold, P. D. Grossfeld, and R. W. Schrier. 1982. Effect of calcium membrane inhibition on norepinephrineinduced acute renal failure. In Acute Renal Failure. H. E. Eliahou, editor. John Libbey, London. 239-240.

11. Weinberg, J. M., and H. D. Humes. 1983. Mitochondrial calcium transport by normal renal cortical mitochondria during their isolation. Kidney Int. 23:202. (Abstr.)

12. Arnold, P. E., D. Lumlertgul, T. Burke, and R. Schrier. 1984. Effect of in vitro versus in vivo mitochrondrial calcium accumulation on mitochondrial function in ischemic acute renal failure. Kidney Int. 25:227. (Abstr.)
13. Murphy, J. B., and M. W. Kies. 1960. Note on spectrophotometric determination of proteins in dilute solutions. Biochem. Biophys. Acta. 45:382-384.

14. Pederson, P. L., J. W. Greenwalt, B. Reynafarje, J. Hullihen, G. L. Decker, J. W. Soper, and E. Bustamente. 1978. Preparation and characterization of mitochondria and submitochondrial particles of rat liver and liver derived tissues. In Methods in Cell Biology. D. M. Prescott, editor. Academic Press, New York. 411-481.

15. Kanerek, L., and R. L. Hill. 1964. The preparation and characterization of fumarase from swine heart muscle. J. Biol. Chem. 239:4202-4206.

16. Pennington, R. J. 1961. Biochemistry of dystrophic muscle. Mitochondrial succinate-tetrazolium reductase and adenosine triphosphatase. Biochem. J. 80:649-654.

17. Griffith, L. D., R. E. Bulger, and B. F. Trump. 1967. The ultrastructure of the functioning kidney. Lab. Invest. 16:220-246.

18. Wilson, D., P. Arnold, T. Burke, and R. Schrier. 1984. Sequential changes in mitochondrial function in ischemic acute renal failure in the rat. Kidney Int. 25:519-526.

19. Goldfarb, D., A. Iaina, I. Serbon, S. Govendo, S. Koupler, and H. E. Eliahou. 1983. Beneficial effect of verapamil in ischemic acute renal failure in the rat. Proc. Soc. Exp. Biol. Med. 172:389-392.

20. Malis, C. D., J. Y. Cheung, A. Leaf, and J. V. Bonventre. 1983. Effects of verapamil in models of ischemic acute renal failure in the rat. Am. J. Physiol. 245:F735-F742.

21. Ishigami, M., N. Stowe, C. Smith, R. Khauli, A. Novick, R. Stroffon, and P. Khairallah. 1983. Protective effect of a $\mathrm{Ca}^{++}$entry blocker in dog kidneys subjected to $120 \mathrm{~min}$ warm ischemia. Fed. Proc. 42:843. (Abstr.)

22. Burke, T. J., P. E. Arnold, and R. W. Schrier. 1981. A role for intracellular calcium in the pathogenesis of norepinephrine (NE)induced acute renal failure (ARF). Clin. Res. 29:457 A. (Abstr.)

23. Burke, T. J., P. E. Arnold, and R. W. Schrier. 1983. Prevention of ischemic acute renal failure with impermeant solutes. Am. J. Physiol. 244:F646-F649.

24. Conger, J. D., and T. J. Burke. 1976. Effects of anesthetic agents on autoregulation of renal hemodynamics in the rat and dog. Am. J. Physiol. 230:652-657.

25. Wait, R. B., G. White, and J. H. Davis. 1983. Beneficial effects of verapamil on post-ischemic renal failure. Surgery. 94:276-282.

26. Blaustein, M. P. 1977. Sodium ions, calcium ions, blood pressure regulation, and hypertension: a reassessment and a hypothesis. Am. J. Physiol. 232:C165-C173.

27. Williams, R. H., C. E. Thomas, L. G. Navar, and A. P. Evan. 1981. Hemodynamic and single nephron function during the maintenance phase of ischemic acute renal failure. Kidney Int. 19:503-515.

28. Humes, D. H., C. F. Simmons, and B. M. Brenner. 1980. Effect of verapamil on the hydroosmotic response to antidiuretic hormone in the toad bladder. Am. J. Physiol. 239:F250-F252.

29. Neufeld, T., D. Terreros, and J. Grantham. 1983. Critical role of calcium in the regulation of intracellular volume of isolated proximal $\mathrm{S}_{2}$ renal tubules in hypotonic medium. Kidney Int. 23:255. (Abstr.)

30. Fiqueiredo, J. F., C. Conti, D. Falkenstein, N. Schor, and O. L. Ramos. 1981. Effect of tetracaine and verapamil on fluid reabsorption by the proximal convoluted tubule of the rabbit. 8th Int. Cong. Nephrol. 194. (Abstr.)

31. Weinberg, J. M., D. Hunt, and H. D. Humes. 1984. Effects of verapamil on in vitro ischemic injury to isolated rabbit proximal tubules. Kidney Int. 25:239. (Abstr.) 
32. Trump, B. F., I. K. Berezesky, K. U. Laiko, A. R. Osorino, W. J. Mergner, and M. W. Smith. 1980. The role of calcium in cell injury. A review. Scanning Electron Microsc. 2:437-462.

33. Fiskum, G., and A. L. Lehninger. 1982. Mitochondrial regulation of intracellular calcium. In Calcium and Cell Function. Vol. II. W. Y. Cheung, editor. Academic Press, New York. 39-80.

34. Mergner, W. J., M. W. Smith, S. Sahaphong, and B. F. Trump. 1977. Studies on the pathogenesis of ischemic cell injury. VI. Accumulation of calcium by isolated mitochondria of ischemic rat kidney cortex. Virchows Arch. B. Cell Pathol. 26:1-16.

35. Arnold, P., D. Lumlertgul, T. Burke, and R. Schrier. 1983. Mitochondrial calcium kinetics in ischemic acute renal failure. Clin. Res. 31:423A. (Abstr.)

36. Kohda, D., and M. Gemba. 1979. Effect of verapamil on the calcium and magnesium transports of rat kidney cortex mitochondria. Jpn. J. Pharmacol. 29:745-751.

37. Nayler, W. G. 1981. The role of calcium in the ischemic myocardium. Am. J. Pathol. 102:262-270.

38. Koomen, J. M., J. A. M. Schevers, and J. Noordhock. 1983 Myocardial recovery from global ischemia and reperfusion: effects of pre- and/or post-ischemic perfusion with low $\mathrm{Ca}^{2+}$. J. Mol. Cell Cardiol. 15:383-392.

39. Clusin, W. T., M. R. Bristow, D. S. Baim, J. S. Schroeder, P. Jallon, P. Brett, and D. C. Harrison. 1982. The effects of diltiazem and reduced ionized calcium on ischemic ventricular fibrillation in the dog. Circ. Res. 50:518-526.

40. Okamatsu, S., and A. M. Lefer. 1983. The protective effects of nifedipine in the isolated cat heart. J. Surg. Res. 35:35-40. 